\title{
Farmers' Willingness to Contract Switchgrass as a Cellulosic Bioenergy Crop in Kansas
}

\author{
Jason E. Fewell ${ }^{\mathrm{a}, 1}$, Jason S. Bergtold ${ }^{\mathrm{b}, 2}$, and Jeffery R. Williams ${ }^{\mathrm{b}, 3}$
}

${ }^{a}$ Director, Farm Business Management, Lake Region State College, 1801 College Drive N., Devils Lake, ND 58301.

${ }^{\mathrm{b}}$ Associate Professor and Professor, Department of Agricultural Economics, Kansas State University, 342 Waters Hall, Manhattan, KS 66506.

${ }^{1}$ Corresponding Author and Present Address: Lake Region State College, 1801 College Drive N., Devils Lake, ND 58301. Tel.: +1 701 6621554. Email: jason.fewell@ lrsc.edu

${ }^{2}$ Tel.: +1 785 5320984. Email: bergtold@k-state.edu

${ }^{3}$ Tel.: +1 785 5324491. Email: jwilliam@k-state.edu 


\begin{abstract}
Farmers' adoption of cellulosic biofuel feedstock enterprises plays an important role in the future of agriculture and the renewable fuels industry. However, no set markets currently exist for bioenergy feedstocks outside of very localized geographic locations and farmers may be reluctant to produce the feedstocks without contracts that help mitigate uncertainty and risk. This study examines farmers' willingness to grow switchgrass under contract using a stated choice approach. Data were collected using an enumerated survey of Kansas farmers and analyzed using latent class logistic regression models. Farmers whose primary enterprise is livestock are less inclined to grow switchgrass. Shorter contracts, greater harvest flexibility, crop insurance, and cost-share assistance increase the likelihood farmers will grow switchgrass for bioenergy production.
\end{abstract}

\title{
Keywords
}

Switchgrass; cellulosic biofuel; stated choice survey; farmer adoption; latent class

\section{JEL codes}

Q1, Q2, Q4 


\section{Introduction}

Much research has assessed the technical feasibility of producing biofuels from lignocellulosic materials on agricultural land in North America (de la Torre Ugarta, English, \& Jensen, 2007; Graham, 1994; Graham, Nelson, Sheehan, Perlack, \& Wright, 2007; Heid, 1984; Gallagher et al., 2003; Perlack et al., 2005; Walsh, de la Torre Ugarte, Shapouri, \& Slinsky, 2003; Nelson et al., 2010). However, technical feasibility studies do not assess "necessary economic and institutional conditions" required by a cellulosic biofuel industry (Rajagopal, Sexton, Roland-Holst, \& Zilberman, 2007). While farmers' ability to produce adequate quantities of biomass for bioenergy throughout the Great Plains has been determined economically feasible, their willingness to do so under different contractual, pricing, and harvesting conditions is relatively unknown, especially with respect to perennial biomass crops such as switchgrass and miscanthus. Large-scale commercial production of these biomass sources is not yet viable economically, and a great deal of uncertainty exists about biomass production, storage, and transportation (Qualls, et al., 2012; Alexander, et al., 2012).

The lack of an established market adds a great deal of uncertainty for farmers during development of this nascent industry. Farmers' willingness to adopt new technologies or practices often depends on their knowledge of the technology or practice and their skills at operating or implementing the practice (Pannell et al., 2006). However, farmers' willingness to grow new crops likely depends not only on knowledge and skill, but also on land tenure, demographic, and social characteristics. Some research has attempted to determine how these factors affect farmers' adoption characteristics with respect to biofuel crops (Bransby, 1998; Hipple \& Duffy, 2002; Jensen et al., 2007; Kelsey \& Franke, 2009; Paulrud \& Laitila, 2010; Qualls, et al., 2012). Farmers will grow bioenergy crops if the returns to the crop outweigh production costs, including opportunity costs (Rajagopal et al., 2007). However, the production 
of dedicated energy crops combined with decreases in traditional crop, forage, and livestock production will cause prices for these displaced commodities to increase in the long term, increasing competition for dedicated energy crops (Dicks et al., 2009; Walsh et al., 2003).

Because biomass markets are not yet established, it is likely farmers will grow bioenergy crops only under contractual relationships that establish pricing, timeframe, harvest parameters, storage requirements, acreage requirements, quality levels, and other arrangements between farmers and biorefineries (Altman, Boessen, \& Sanders, 2007; Epplin et al., 2007; Glassner, Hettenhaus, \& Schechinger, 1998; Larson, English, \& Lambert, 2007; Stricker, Segrest, Rockwood, \& Prine, 2000; Wilhelm, Johnson, Hatfield, Voorhees, \& Linden, 2004). Disparities between biorefineries and farmers' views about the value of the biomass necessitate careful contract design so all parties are satisfied.

A potential bioenergy crop in the Great Plains is switchgrass. Switchgrass planting decreases soil erosion over cultivation, uses less nitrogen fertilizer than corn, requires lower herbicide applications except in the establishment year, and is both more drought and flood tolerant than traditional crops (McLaughlin \& Walsh, 1998). However, switchgrass production is less likely to occur on highly productive land and may be more suitable for marginal land or land already enrolled in conservation programs, such as CRP, to increase revenue (Paine et al., 1996). Paine et al. (1996) recommended growing switchgrass and other perennial energy crops on marginal lands, such as highly erodible land (HEL), poorly drained soils or areas used for wastewater reclamation, which would avoid competition with food crops and increase the amount of arable land. HEL land is generally unsuitable for residue removal, but potentially viable for perennial energy crop production. USDA (2006) states that switchgrass requires few field passes and little soil disturbance resulting in low soil erosion rates. 
The purpose of this study is to determine farmers' willingness to grow switchgrass as a bioenergy crop while helping facilitate contract design and biomass price establishment. With farm profitability expected to decline in 2015 from record highs during the period 2011 to 2013, it is even more important to assess whether farmers are willing to enter into bioenergy crop enterprises or continue with their established practices. A stated choice survey was developed to elicit Kansas farmers' willingness to grow switchgrass as a bioenergy crop under alternative contractual, pricing, and harvesting arrangements. The stated choice format allows farmers to choose among alternatives following Hensher, Rose, and Greene (2005) and survey results are analyzed using a latent class conditional logistic regression model (Greene \& Hensher, 2003).

The next section discusses growing switchgrass as a bioenergy crop, followed by a description of the survey and data. The conceptual model and econometric analysis follow the survey discussion. Finally, the results and conclusions finish the paper.

\section{Switchgrass as a Bioenergy Crop}

The viability of producing switchgrass as a bioenergy feedstock in the Great Plains has been the topic of much research (Perlack et al., 2005; Mapemba \& Epplin, 2004; Epplin et al., 2007; Bangsund, DeVuyst, \& Leistritz, 2008; Perrin, Vogel, Schmer, \& Mitchell, 2008).

Switchgrass is a perennial grass, native to much of the Great Plains, and has been identified as a significant potential bioenergy crop based on research conducted across 31 locations over several years in the late 1980s and early 1990s. It requires low maintenance after its establishment phase, is noninvasive, and is suited to many soil types in different parts of the country, including marginal lands not as productive for high-value crops such as corn or soybeans (Wright, 2007). Harvesting, transporting, and storing switchgrass is similar to well-established hay production practices (Wright, 2007), although long-term biomass storage may reduce ethanol yields (Rigdon, Maier, Vadlani, \& Jumpponen, 2011). 
Production costs for switchgrass in the initial establishment phase vary depending on the amount of field preparation needed, fertilizer needs, and seeding rate. Establishment costs can range from about $\$ 150$ to $\$ 200$ per acre while yield during the first two years' of production are reduced until the crop becomes fully established (Griffith, Epplin, \& Redfearn, 2010). Annualized costs of establishing switchgrass are between $\$ 20$ and $\$ 30$ per acre over 10 years. Annual production costs can range from $\$ 175$ to $\$ 285$ per acre, depending on biomass yields (2 to 6 tons per acre), transportation costs, and capital costs (Griffith et al., 2010). Switchgrass is planted in the spring and weeds are controlled via spraying, mowing, or grazing (Ohlenbusch, 1997). After the crop is well established, 90 to 120 pounds of nitrogen fertilizer can be applied to increase production, followed by phosphorus and potassium if soil testing warrants it (Ohlenbusch, 1997; Teel, Barnhart, \& Miller, 2003). Fertilizer rates and costs will vary depending on soil requirements and location.

McLaughlin et al. (2002) determined there is potential to produce switchgrass in the United States east of the Rocky Mountains on 16.9 million acres at a price of $\$ 39.92$ per short ton at the farm gate. This price may entice farmers to plant switchgrass rather than traditional crops if yields are high. However, record-high commodity prices in recent years may preclude farmers' planting of switchgrass in favor of traditional cash crops.

\section{Materials and Methods}

A stated choice survey was administered from November 2010 to February 2011 in three areas of Kansas by Kansas State University and the USDA, National Agricultural Statistics Service (NASS). The survey assessed farmers' willingness to produce three different types of cellulosic biomass: corn stover, sweet sorghum, and switchgrass for bioenergy production under different contractual arrangements. The paper here focuses on the switchgrass experiment. A total of 485 farmers were contacted in northeastern, south central, and western Kansas counties 
to participate in the survey (Figure 1). These areas of Kansas were selected based on the number of farms growing corn and/or sorghum and the mix of irrigated and dryland production. The sample of farms was randomly drawn from the population of farms over 260 acres in size and $\$ 50,000$ in gross farm sales from the USDA-NASS farmer list for each area of the state examined. Farmers already participating in other USDA-NASS enumerated surveys (e.g., ARMS) were removed from the sample and replaced with another randomly drawn name. Prior to the survey entering the field, the stated choice component was field tested with two focus groups at an annual extension conference hosted by the Department of Agricultural Economics at Kansas State University in the summer of 2010. Participants who were identified as farmers were invited to attend the focus group, of which 12 participated. In addition, the entire survey was tested using face-to-face interviews with farmers in the targeted study areas.

Potential participants received a four-page flier via mail asking for their participation in the survey and providing information about cellulosic biofuel feedstock production on-farm one week prior to being contacted by USDA-NASS enumerators. Enumerators then scheduled onehour interviews with the farmers to complete the survey and stated choice experiments. Interviews, on average, took 57 minutes to complete. Upon completion of the survey and receipt at the USDA-NASS office, farmers were compensated for their time with a $\$ 15$ gift card. Of the 485 farmers contacted, 290 completed the survey and 38 were out-of-business, did not farm, or could not be located. Thus, the survey response rate was $(290 /(485-38))=0.65$ or 65 percent. Of the 290 respondents who completed the stated choice experiment for switchgrass, six surveys were incomplete due to lack of responses on the switchgrass experiment or refusal to answer demographic questions, leaving 284 usable surveys for this study. 


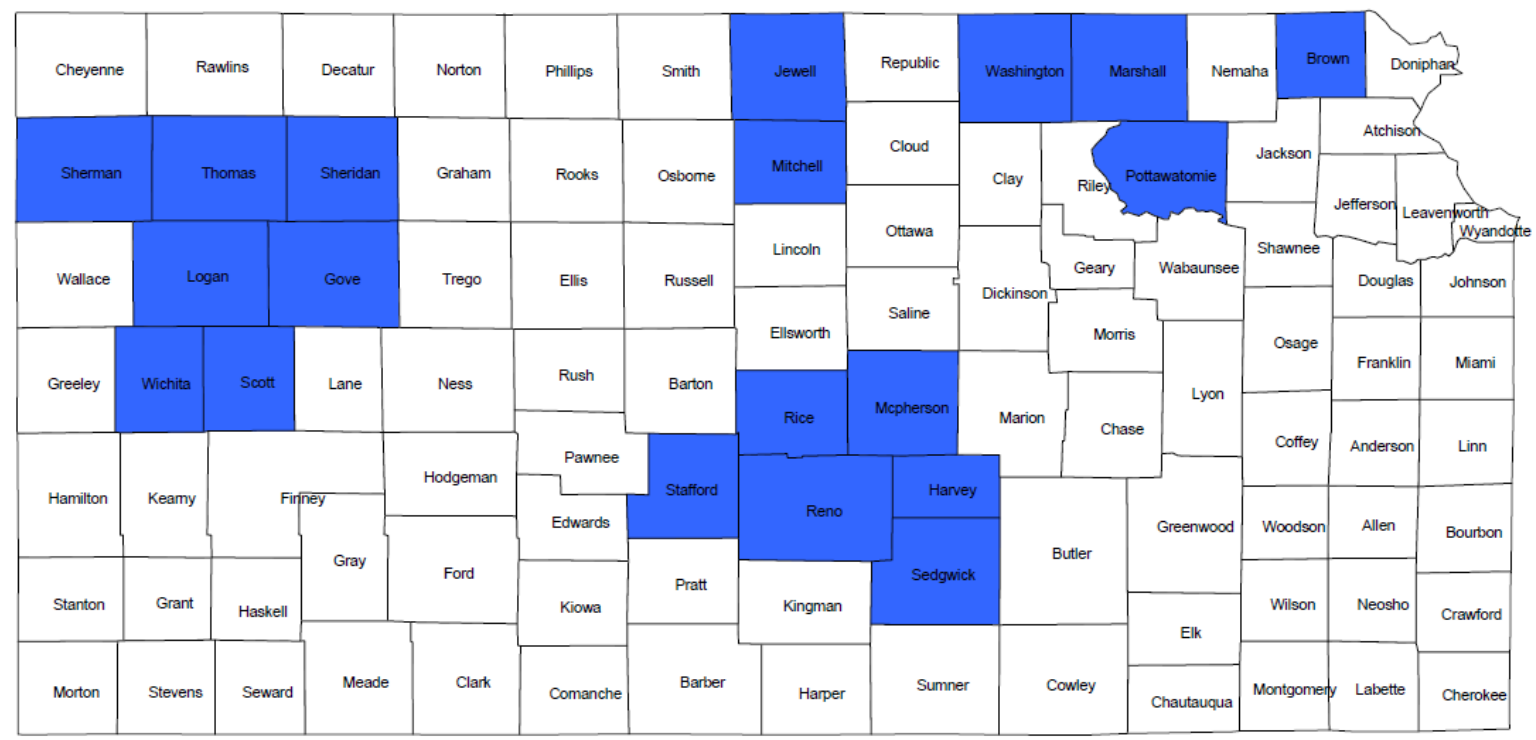

Figure 1. Map of state of Kansas with survey areas highlighted.

After answering a number of questions about their farming operation, respondents were asked about their willingness to produce switchgrass as a cellulosic biofuel feedstock under contract. Respondents were then asked about biofuel feedstock production preferences and perceptions; conservation on-farm and perceptions; risk management practices and perceptions; crop marketing practices; and demographics.

Farmer demographic data from the 2012 U.S. Census of Agriculture (National Agricultural Statistics Service, 2013) were used to determine whether the survey respondents were representative of Kansas farmers. Table 1 compares some of the demographics reported by farmers in the survey to statewide numbers as recorded in the 2012 Census of Agriculture. The percentage of farmers who identified themselves as white or Caucasian is approximately the same for both the census and survey. A slightly lower average age is reasonable given our survey sampled larger farms that are likely to be operated by younger farmers. Average farm size and 
amount of rented land are considerably larger for our survey, which may be due to the focus on farms growing crops. More of the survey respondents are male than in the Census figures. Average value of agricultural products found in the survey includes the value reported by Census figures. The survey asked respondents to choose a range in which their agricultural value of sales fell, and the range chosen most often matches closely to the Census data.

Table 1. Comparison of Kansas farmer demographics to survey respondents.

\begin{tabular}{lcc}
\hline & 2012 Census of Agriculture $^{\mathrm{a}}$ & Survey \\
\hline Percent white & $99.2 \%$ & $98.9 \%$ \\
Age & 58.6 years & 55.9 years \\
Percent male principal & $93.4 \%$ & $95.9 \%$ \\
operators & 1553 acres & 2147 acres \\
$\begin{array}{l}\text { Average size of farm } \\
\text { Average amount of }\end{array}$ & 722 acres & 1388 acres \\
rented land in farm & \\
Average market value of & $\$ 448,317$ & $\$ 200,000$ to $\$ 399,999^{\mathrm{d}}$ \\
agricultural products $^{\mathrm{c}}$ & &
\end{tabular}

${ }^{a}$ Source: USDA, National Agricultural Statistics Service. 2013 Census Publications.

b2012 Census of Agriculture descriptive statistics where calculated for farms above 260 acres in size.

'2012 Census of Agriculture descriptive statistics where calculated from farms above 260 acre in size and $\$ 50,000$ in gross farm sales.

${ }^{\mathrm{d}}$ Category represent the one chosen with the highest frequency.

\subsection{The Stated Choice Experiment}

A stated choice experiment was designed to assess farmers' willingness to produce switchgrass for biofuel under contract with biorefineries or other biomass processors following Louviere, Hensher, and Swait (2000) and Roe, Sporleder, and Belleville (2004). The survey provided a brief explanation of switchgrass production and explained the contract attributes shown in Figure 2 before requiring a response to a set of stated choice questions following the format exhibited in the example in Figure 3. Survey respondents were asked to consider five independent choice sets with options to choose between two contracts or an "opt out" option. Contract options were unlabeled and had five attributes: (1) Net returns above CRP or Hay Production, (2) Contract Length, (3) Bio-refinery Harvest Option, (4) Insurance Availability, and 
(5) Seed Cost-Share Provision. Descriptive statistics for the attributes and levels are shown in Table 2 and discussed in Section 3.2.

\subsection{Net Return Choice Attribute}

It was assumed that farmers would prefer to plant switchgrass on marginal land (that may not be renewed in the Conservation Reserve Program (CRP), a federal land retirement program) or that is currently under hay or grass production. The survey states, "Switchgrass is a perennial crop that can be grown in place of other annual crops, on hay land or less productive lands (e.g. CRP land)". Therefore, net returns are not fixed to a specific dollar amount, but can be compared relative to other crops or land use options such as hay production or CRP. Three levels of net returns considered are: 5\%, 20\%, and 35\%. Using the percentage net returns above hay production or CRP rental payments as a base (assumed to be about $\$ 40$ per acre based on the level of average net returns from Kansas Farm Management Association Farms (KFMA) in the study region(s) for 2008/9 (KFMA, 2010), see Figure 2), a market price for biomass can be determined using production costs and crop yields, without putting a precise monetary value on the biomass. In addition, using the percentage net return above hay production or CRP rental payments will allow prices to "float" to levels that will entice farmers to adopt switchgrass. Policy makers and the biofuel industry will benefit from the survey results because they will know whether farmers are willing to supply biomass, while realizing prices required before farmers adopt. Thus, the net returns attribute provides flexibility in allowing the capture of reservation prices and potential opportunity costs. To the authors' knowledge this approach for incorporating net returns and the next best land use alternative have not been considered in a stated choice experimental framework. 


\section{SECTION 2A}

This section will ask about your willingness to supply switchgrass, a perennial bioenergy crop, to a bio-refinery or intermediate processor (e.g. cooperative) through different contractual agreements. You will be asked to consider 5 scenarios. Each scenario contains three options: two contract options and one for "do not adopt." The final option provides the option to "opt out" if the contracts presented are not favorable to you. Each contract will have different features, which include net returns per acre, contract length, a harvest option, an insurance availability option, and a cost-share provision option.

Switchgrass is a perennial crop that can be grown in place of other annual crops, on hay land, or less productive lands (e.g. CRP land). Harvesting of switchgrass involves cutting, raking and then baling the stalks. Switchgrass has a two-year establishment period with no harvest in the first year, a reduced yield in year two, finally reaching full yield potential in year three. Replanting occurs about every 10 years. Expected biomass yields for switchgrass range from 1 to 8 dry tons per acre, but yields will vary depending on climatic conditions and geography. In the future, biomass yields are expected to increase with improvements in plant breeding and harvest technology. Biomass harvesting can be done by the farmer (with his/her own equipment or by hiring a custom operator) or by the biorefinery. Harvesting would take place in the late fall or could occur during the winter. The annual average cost of production for a switchgrass enterprise ranges from $\$ 44$ to $\$ 142$ per acre. In the following scenarios, the bio-refinery will be responsible for long-term storage of biomass; a minimum acreage contract will be negotiated between the bio-refinery and farmer; and the contract will include an "Act of God" clause.

Each scenario presented will present different contractual options with the following features:

\begin{tabular}{|c|c|}
\hline Contract Feature & Description \\
\hline $\begin{array}{l}\text { Net Returns } \\
\text { (for all features of the } \\
\text { contract except the } \\
\text { seed/establishment costs) }\end{array}$ & $\begin{array}{l}\text { Represents the expected percentage gain under the contract above net returns } \\
\text { associated with hay production and/or CRP rental payments on your operation. As a } \\
\text { reference point, on average, returns from hay production or income from land in CRP } \\
\text { are expected to be around } \$ 40 \text { per acre in Kansas. } \\
\text { For example, if your CRP rental rate is } \$ 40 / \text { acre, a } 10 \% \text { return above } \$ 40 \text { per acre } \\
\text { will be } \$ 44 / \text { acre. This amount is received after all expenses, including harvest and } \\
\text { insurance are paid, but does not include the seed/establishment cost-share payment. }\end{array}$ \\
\hline Contract Length & Represents the time commitment in consecutive years of the contractual agreement. \\
\hline Bio-refinery Harvest & $\begin{array}{l}\text { "Yes" indicates the bio-refinery will harvest the biomass at their expense, and "No" } \\
\text { means the farmer is responsible for harvest (including cutting, raking, baling and } \\
\text { transportation to the bio-refinery). Harvest charges are included in the percentage net } \\
\text { return. That is, the charges are considered paid regardless of who harvests the } \\
\text { biomass. }\end{array}$ \\
\hline Insurance Availability & "Yes" indicates crop insurance is available, and "No" otherwise. \\
\hline $\begin{array}{c}\text { Seed/Establishment } \\
\text { Cost-Share }\end{array}$ & $\begin{array}{l}\text { Indicates a percentage of seed/establishment costs are covered or cost-shared by the } \\
\text { bio-refinery or processor during the first two years of production or after planting due } \\
\text { to lower yields during the establishment period. Establishment costs can range from } \\
\$ 150 \text { to } \$ 200 \text { per acre. This will be provided every time the crop is replanted. This } \\
\text { cost-share is provided in addition to the net returns indicated above. }\end{array}$ \\
\hline
\end{tabular}

Figure 2. Explanation of switchgrass production practices, costs, and contract attribute descriptions 
Switchgrass Scenarios - For each scenario evaluate the contractual options and please rank the contract options in the order that you would prefer them with $1=$ first choice, $2=$ second choice, and $3=$ third choice.

\section{Scenario 1:}

CONSIDER EACH SCENARIO INDEPENDENTLY.

\begin{tabular}{|c|c|c|c|c|}
\hline & & Contract A & Contract B & Option C \\
\hline \multirow{6}{*}{ 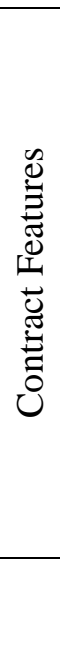 } & $\begin{array}{c}\text { Net Return Above Hay } \\
\text { Production/CRP Rental } \\
\text { Rates } \\
\text { (Base: } \$ 40 / a c) \\
\end{array}$ & $35 \%$ Higher/year & $5 \%$ Higher/year & \multirow{5}{*}{ Do Not Adopt } \\
\hline & Contract Length & 7 Years & 16 Years & \\
\hline & Bio-refinery Harvest & Yes & No & \\
\hline & Insurance Available & No & Yes & \\
\hline & $\begin{array}{c}\text { Seed/Establishment } \\
\text { Cost-Share }\end{array}$ & $70 \%$ & $35 \%$ & \\
\hline & $\begin{array}{c}\text { Your Ranking } \\
(1-3)\end{array}$ & & & \\
\hline
\end{tabular}

Figure 3. Example of stated choice question for a switchgrass choice scenario

\subsubsection{Contract Length Attribute}

Contract length has two levels: 7 years and 16 years. Since switchgrass is planted approximately once every ten years, a producer may wish to enter into a contract length of at least seven years. If they choose to continue producing switchgrass, it is possible they would enter into a contract for 16 (or more) years, replanting at year 10. In addition, 7- and 16-year contracts allow a producer to discontinue switchgrass production if they choose to transition their land back into regular crop or hay production or into CRP before a traditional planning and production cycle is complete and prior to the switchgrass needing replanting. ${ }^{1}$

\footnotetext{
${ }^{1}$ Contract lengths of 7- and 16-years were chosen to allow the farmer the option to opt out of the contract before the 10 life-span of the switchgrass stand was reached. A farmer may want this option if the switchgrass enterprise is relatively less profitable than other land use options. In addition, the assumption was made that producers may be more willing to adopt a contract with the knowledge that they would not be locked into a contract for the entire 10year span that the switchgrass should live. If they chose to do so, they would have the option to convert the switchgrass to other crop/livestock enterprises should some opportunity present itself. At the same time, the 7- and 16-year contracts ensure production for the biorefinery for a sufficient number of years.
} 


\subsubsection{Binary and Cost Share Attributes}

All binary attributes are effects coded, which helps capture the grand mean of farmers' utility functions (Hensher, Rose, \& Greene, 2005) because assigning a zero to the value of a binary variable in this case would indicate the attribute is not included in the scenario. Binary attributes include: (i) biorefinery harvest, which offers a custom harvest option at the biorefinery's expense and flexibility to the farmer; and (ii) insurance availability, which indicates whether a crop-insurance type instrument is available for farmers to purchase under the biomass contract. The final attribute is seed-cost share, which is included at three levels: $0 \%, 35 \%$, and $70 \%$. The high cost of establishing switchgrass may necessitate the bio-refinery's sharing in seed costs.

\subsubsection{Experimental Design}

Following Louviere et al. (2000), a collective factorial design is adopted for the stated choice experimental set-up, which combines all attributes for all options (i.e. Contract A, Contract B and "Do Not Adopt) in a choice set into one experimental design. The size of the collective factorial is $\left(L^{A}\right)^{M}$, where $M$ is the number of options in the choice set; $A$ is the number of attributes for each option; and $L$ is the number of levels for a given attribute. A fractional factorial design was then obtained from the collective factorial to obtain the number of choice sets that would allow identification of all main effects and potential interaction effects between

contract attributes and levels. A $\left(2^{4} \times 3^{2}\right)^{2}$ fractional factorial experimental design was used to design the choice sets for the switchgrass experiment. PROC OPTEX in SAS (2008) was used to develop the fractional factorial design from the complete factorial to obtain 90 random choice scenarios, which are then blocked into 18 choice sets of 5 choice scenarios each. The $D$ optimality criterion was used to obtain an optimal design using a modified Federov search algorithm (see Nguyen and Miller, 1992). Optimal blocking was determined following the 
method outlined in Cook and Nachtsheim (1989). Thus, in each version of the survey, a respondent was asked to consider 5 choice sets for producing switchgrass under contract, resulting in 18 versions of the survey (from blocking). In addition, with the 5 choice sets for each respondent and 284 complete surveys, there were 1420 observations for model estimation. The optimal D-Efficiency (Treatment D-Efficiency) for the switchgrass choice experiment design was 91.73 (77.61). Of the 290 surveys completed, 12 to 20 of each version were obtained.

\subsection{Summary Statistics}

The most popular first choice among respondents was "do not adopt" with 1047 of 1420 responses, as noted in Table 2 . Thus, only $26.3 \%$ of the responses were for a contract (either A or B). In the case of the stated choice experiment, it is likely respondents did not find the contract attributes favorable on average. This was expected with an enterprise such as switchgrass. A great deal of uncertainty surrounds switchgrass production with regard to yield, seed availability, establishment, production, maintenance costs, and net returns. In addition, establishing a crop for seven years (or more) causes some hesitation due to uncertainty with regard to opportunity costs of not growing traditional crops or hay, as well as not receiving potential CRP payments on retired marginal land. Finally, farmers may be reluctant to enter into such long-term contractual arrangements.

\section{Conceptual Model and Econometric Analysis}

\subsection{Theoretical Approach}

Following Roe et al. (2004), we assume producers maximize expected discounted random utility when they choose to enter into a switchgrass contract instead of producing hay or CRP. Producer $i$ 's expected discounted utility for contract $j$ is:

$$
V_{i, j}=V\left(\Delta R_{j}, C_{j}, H_{j}, I_{j}, S_{j}, L_{k i}\right)+\varepsilon_{i, j}
$$


where $\Delta R_{j}$ is the level of net returns above CRP or hay production over time, $C_{j}$ is the contract length in years, $H_{j}$ is the biomass harvest option, $I_{j}$ is biomass crop insurance availability, and $S_{j}$ is the level of establishment cost-share. Due to variation in climate and growing conditions across Kansas, a fixed effects location parameter, $L_{k i}$, is added to account for farmers in the northeast, west, or central portions of the state. Finally, the error term, $\varepsilon_{i, j}$, represents the nonsystematic part of expected utility that is unobserved by the researcher and is assumed to be distributed Type I extreme value (Louviere et al., 2000; Train, 2003). It should be re-emphasized here that the model explicitly takes account of the opportunity costs to producing switchgrass with the net returns variable being the returns above the next best alternative, which is assumed to be hay production or retiring the land and receiving CRP payments.

A farmer will choose the contract option (A or B) that provides the highest level of discounted utility. Assuming farmer $i$ 's expected discounted utility is linear in the attributes or variables, where $\mathbf{x}_{j}$ is a matrix of contract attributes for option $j$ and $\boldsymbol{\beta}$ is a vector of parameters, the farmer will solve the problem:

$$
V_{i, j}=\beta \mathbf{x}_{j}+\varepsilon_{i, j}=\max \left(V_{i, 1}, \ldots, V_{i, J}\right) .
$$

Given the researcher only observes the choice of which contract option is selected, a probabilistic discrete framework is adopted to evaluate the choice. If the residuals, $\varepsilon_{i, j}, j=1, \ldots, J$ are independently distributed with extreme value distribution, then the probability of a farmer choosing contract option $j$ can be represented as (Train, 2003):

$$
\operatorname{Prob}(\text { farmer } i \text { choose option } j)=\frac{\exp \left(\beta^{\prime} \mathbf{x}_{j}\right)}{\sum_{j=1}^{J} \exp \left(\beta^{\prime} \mathbf{x}_{j}\right)} \text {, for } j=1, \ldots, J
$$


Table 2. Attribute descriptions and summary statistics of contract attributes and levels for each randomly assigned contract type for the entire sample versus those who chose a contract as their 1st choice.

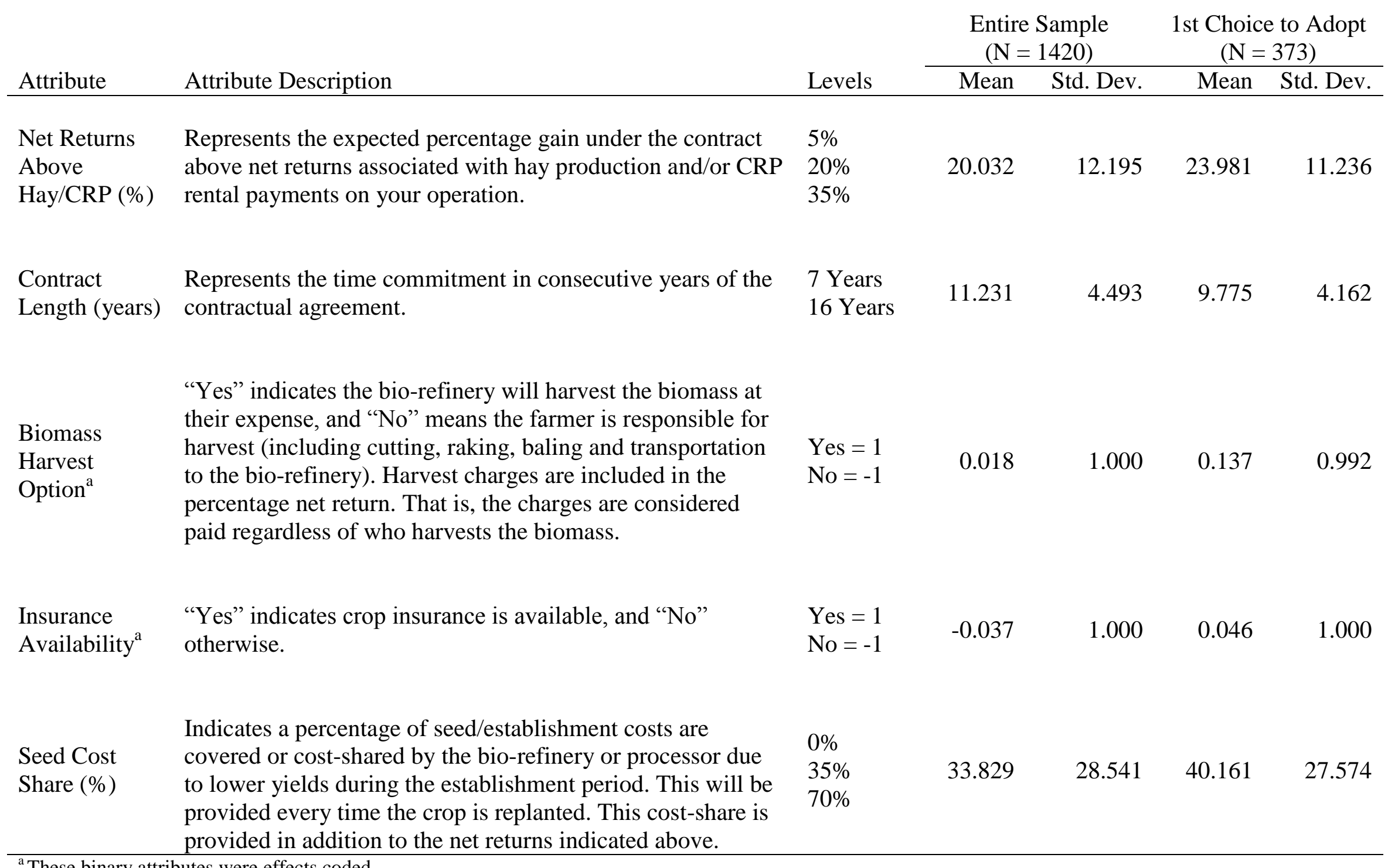




\subsection{Econometric Model Specification}

A latent class conditional logistic regression (LCM) model is adopted for the econometric specification because of the discrete nature of the stated choice experiment and the approach is able to take account of unobserved characteristics across respondents, as well as latent heterogeneity from unobserved factors (Greene \& Hensher, 2003) ${ }^{2}$. The LCM allows for the relaxation of the independent and irrelevant alternatives (IIA) assumption between classes in the multinomial model, but does impose IIA within classes (Greene, 2007). Finally, Boxall and Adamowicz (2002) indicated that random parameter models, while allowing parameters to vary over individuals, do not necessarily explain sources of heterogeneity adequately compared to latent class models..

Following Greene and Hensher's (2003) theoretical framework, the probability of farmer $i$ from class $q(q=1,2, \ldots, Q)$ choosing alternative (contract) $j$ for choice situation $\tau(\tau=1,2, \ldots$ $T)$ is:

$$
\begin{aligned}
& \operatorname{Prob}[\text { individual } i \text { choosing choice } j \text { in situation } \tau \mid \text { class } q]= \\
& \qquad \exp \left(\boldsymbol{\beta}_{q}^{\prime} \mathbf{x}_{\tau, j}\right) / \sum_{j=1}^{J} \exp \left(\boldsymbol{\beta}_{q}^{\prime} \mathbf{x}_{\tau, j}\right)
\end{aligned}
$$

where $\mathbf{x}_{\tau, j}$ is a matrix of contract attributes for option $j$ in choice situation $\tau$ and $\boldsymbol{\beta}_{q}$ is a vector of coefficients for individuals in class $q$. Following Greene and Hensher (2003), this can be written

as

$$
P_{i \tau \mid q}(j)=\operatorname{Prob}\left(y_{i \tau}=j \mid \text { class }=q\right),
$$

\footnotetext{
${ }^{2}$ The authors' tested the appropriateness of the LCM with multiple levels of classes and determined that 2 provided the most reasonable explanation of the results and was the most statistically-relevant model. In addition, models were estimated with fewer farmer characteristics, but these models were not as parsimonious. Excluding further farm characteristics lessened the explanatory power of the model and would have ignored characteristics captured in the LCM. In addition, other methods such as random parameters logit and conditional logit were ran and tested, but it was determined they provided less explanatory power. Given knowledge about the characteristics of the farmers, an objective of the model was to determine sources of heterogeneity across farmers - not just that heterogeneity existed.
} 
where $y_{i \tau}=j$ is an indicator variable identifying the choice of contract for farmer $i$ in situation $\tau$.

The probability that an individual, $i$, will fall into a certain class, $q$ is given by:

$$
P_{i \mid q}=\prod_{\tau=1}^{\mathrm{T}} P_{i \tau \mid q}
$$

Latent class probabilities sum to one, so the model is only able to estimate $Q-1$ latent classes. A common form to estimate the class probability is a traditional multinomial logit discriminant of the form:

$$
M_{i q}=\exp \left(\boldsymbol{\gamma}_{q}^{\prime} \boldsymbol{\alpha}_{i}\right) / \sum_{q=1}^{Q} \exp \left(\boldsymbol{\gamma}_{q}^{\prime} \boldsymbol{\alpha}_{i}\right), q=1, \ldots, Q \text { and } \boldsymbol{\gamma}_{Q}=0
$$

where $M_{i q}$ is the latent class constant probability for all individuals in class $q, \boldsymbol{\alpha}_{i}$ is a vector of respondent $i$ 's characteristics and $\gamma_{q}$ is the latent class parameter estimates. Combining equations (6) and (7) provides the likelihood that an individual will fall into class $q$ :

$$
P_{i q}=\sum_{q=1}^{Q} M_{i q} P_{i \mid q}
$$

This model formulation allows both contract attributes and respondent characteristics to determine the overall choice probabilities (Boxall \& Adamowicz, 2002).

\subsection{Empirical Modeling}

This study's primary interest is assessing direct impacts of contract attributes on farmers' willingness to accept a contract. Therefore, following Roe et al. (2004), the focus becomes the reduced-form representation of expected random utility. A main effects model (Greene, 2007; Louviere et al., 2000) for producer $i$ and contract $j$ is posited as:

$$
V_{i, j}=\beta_{0}+\beta_{1} \Delta R_{j}+\beta_{2} C_{j}+\beta_{3} H_{j}+\beta_{4} I_{j}+\beta_{5} S_{j}+\beta_{6} \text { Cent }_{i}+\beta_{7} \text { East }_{i}+\varepsilon_{i, j}
$$

for $j=A, B$, or $C$. Contract options A and B represent the randomly assigned, unlabeled contract options for each scenario, while Option C is the "opt out" option. Option C does not contain any 
attributes, so $\beta_{1}=\cdots=\beta_{5}=0$ and $V_{C, i}=\beta_{6}$ Cent $_{i}+\beta_{7}$ East $_{i}+\varepsilon_{i, j}$. This allows the model to control for unobserved individual effects associated with "opting out."

Assuming farmers are profit maximizers, the signs for $\beta_{1}$ and $\beta_{5}$ are expected to be positive since higher net returns and lower-cost seed can both contribute to increased profit. Farmers likely prefer short-term contracts, so the sign of $\beta_{2}$ should be negative. The sign for $\beta_{3}$ may be either positive or negative depending on farmers' views about bio-refinery harvest being a cost-saving attribute, or if farmers are reluctant to allow custom operators on their property and location. The sign for $\beta_{4}$ is expected to be positive since farmers will likely prefer insurance availability as a tool to manage risk, especially for crops with which they have little experience.

While respondents were asked to rank their contract options, not all respondents did so, indicating only there preferred option. Thus, the paper only examines respondents' first choice. In other words, we examine whether they would adopt a contract or not. Louviere, et al. (2000) states that, while ranking of options provides more information, it may not be reliable when only some respondents rank all options or only provide partial rankings. Given the discrete nature, a LCM model is estimated in NLOGIT 4.0 following the empirical model specification provided above. The model uses simulated maximum likelihood with Halton draws using the BFGS algorithm (Greene, 2007). Predicted probabilities and farmers' willingness to pay for alternative contractual attributes are calculated using model estimates. Standard errors for all statistics using model results are calculated using the delta method following Greene (2008).

The LCM is estimated with the contract attributes and other farmer characteristics to determine how farmers make decisions amid unobserved classes. Farm and farmer variable characteristics $\left(\boldsymbol{\alpha}_{i}\right)$ in the LCM are shown in Table 3. The number of crop acres may indicate that larger crop producers may be more willing to adopt another enterprise if they see a benefit to 
further diversification. Availability of hay and CRP acres may indicate whether a farmer has familiarity with growing hay or receives CRP payments, both of which form the basis for the net revenue contract attribute. The percent of cash-rented acres should have a negative sign because it is expected that farm operators who rent more land on a cash basis will be reluctant to plant a perennial crop such as switchgrass because they may or may not rent the land for the duration of the crop's life. The variables livestock and baler indicate whether a farmer produces livestock or owns a baler. Farmers with livestock may be unwilling to adopt a switchgrass enterprise because they will use most of their hay acres to feed livestock, and many farmers who own a baler may use it predominantly for hay production. However, it is still important to include the variable because farmers who own a baler may be more familiar with baling biomass as well as more willing to bale biomass for bioenergy. Age and college are included in the model to determine if older, younger, and more or less educated farmers are willing to adopt a switchgrass enterprise. Younger farmers may be more willing to try something new if they are trying to diversify their operations or competing for land. Older farmers may be more willing to maintain their operations "as is" rather than adopt new enterprises. Finally, the risk aversion variable is useful to determine if farmers' self-identification of risk aversion affects their willingness to adopt a switchgrass enterprise in spite of yield and cost of production uncertainty and the lack of a liquid cellulosic biofuel market. Caldas et al. (2014) indicates that risk aversion could impact farmers' willingness to adopt a perennial bioenergy crop option. Using these variables to determine the latent classes will explain how farmers' characteristics affect their willingness to adopt a switchgrass contract, which all have been considered in prior adoption studies (Jensen et al., 2007; Kelsey \& Franke, 2009; Colombo, Hanley, \& Louviere, 2009). 
Table 3. Summary statistics for farm and farmer characteristics included in latent class probabilities. $(N=284)$

\begin{tabular}{|c|c|c|c|c|c|}
\hline Variable & Mean & $\begin{array}{c}\text { Standard } \\
\text { Deviation }\end{array}$ & Maximum & Minimum & Description \\
\hline Crop acres & 1,556 & 1,398 & 8620 & 0 & $\begin{array}{l}\text { Number of acres used to } \\
\text { produce crops. }\end{array}$ \\
\hline Hay acres ${ }^{a}$ & 72 & 100 & 500 & 0 & $\begin{array}{l}\text { Number of acres used to } \\
\text { produce hay. }\end{array}$ \\
\hline CRP acres ${ }^{a}$ & 34 & 106 & 1,200 & 0 & $\begin{array}{l}\text { Number of acres enrolled in } \\
\text { Conservation Reserve } \\
\text { Program (CRP). }\end{array}$ \\
\hline Percent Cash Rent & $32 \%$ & $39 \%$ & $100 \%$ & $0 \%$ & $\begin{array}{l}\text { Percent of rented acres } \\
\text { rented on a cash basis. }\end{array}$ \\
\hline Livestock $^{\mathrm{b}}$ & $61 \%$ & & & & $\begin{array}{l}\text { Percent indicating they have } \\
\text { livestock. }\end{array}$ \\
\hline Use a baler ${ }^{b}$ & $59 \%$ & & & & $\begin{array}{l}\text { Percent indicating they use a } \\
\text { baler. }\end{array}$ \\
\hline Age (years) & 56 & 12 & 85 & 24 & \\
\hline College $^{b}$ & $30 \%$ & & & & $\begin{array}{l}\text { Percent indicating they have } \\
\text { a college education. }\end{array}$ \\
\hline Risk Averse ${ }^{b}$ & $89 \%$ & & & & $\begin{array}{l}\text { Percent indicating they are } \\
\text { averse to risk following } \\
\text { Caldas et al. (2014). }\end{array}$ \\
\hline
\end{tabular}

${ }^{a}$ Note that 175 (61.6\%) farms had hay or forage acres and 82 (28.8\%) had CRP land.

${ }^{\mathrm{b}}$ Binary variables.

For a more detailed description of the data used in the survey, please see Fewell, et al., (2013).

\section{Results}

Table 4 provides estimation results for the latent class model. Model fit statistics show a good fit. The McFadden's Pseudo- $\mathrm{R}^{2}$ of 0.56 indicates the full model including all variables is more likely to occur than an intercept-only model. The model was run with two, three, four, and five latent classes to determine the optimal number of classes. Using the AIC is a common method to determine the appropriate number of classes (Breffle, Morey, \& Thacher, 2011; Colombo et al., 2009; Meyerhoff, Bartczak, \& Liebe, 2012). Running the model with two latent classes provided the lowest AIC and a more cogent interpretation of the classes. These two 
classes group farmers into crop farmers and crop-livestock farmers. Coefficients' signs for the contract attributes are in line with predictions, where only contract length has a negative effect on a farmer's utility of adopting a switchgrass enterprise. Regional variables indicate that farmers in central Kansas are more likely to adopt a switchgrass enterprise than those in eastern Kansas. This is likely due to farmers in eastern Kansas raising primarily corn and soybeans, which have been very profitable in recent years.

\subsection{Latent Class Model Results}

Interpreting the latent classes is seldom a straightforward exercise. By themselves, the coefficient estimates for the latent classes have little meaning (Greene \& Hensher, 2003). However, the classes can be interpreted based on how respondents' characteristics become categorized, taking care to interpret them relative to the base category (where class, or segment parameter estimates are fixed to estimate the model) and each other (Boxall \& Adamowicz, 2002). In addition, examining the descriptive statistics of the respondents in each latent class may be informative.

Table 5 contains descriptive statistics of the latent classes for the independent variables. Farmers in latent class one have fewer crop acres, fewer hay acres, more CRP acres, and are slightly older, on average. Approximately $54 \%$ of the farmers in latent class one indicated they raise livestock and have a baler, while $77 \%$ and $71 \%$, respectively of those in latent class two raise livestock and have a baler. About $32 \%$ of farmers in latent class one have a college education while about $26 \%$ in latent class two indicated they are college educated. An equal number of farmers in each class indicated they are risk averse. Farmers in both classes earn about $29 \%$ of their income from livestock. Those in latent class one earn about $76 \%$ of their income from crop sales and those in latent class two earn about $70 \%$ of their income from crop sales. The latent class coefficient estimates for latent class 1 indicate these farmers likely rent less land 
and raise less livestock, which is supported by the descriptive statistics in Table 5. Thus, we assume these farmers may be more crop-oriented than farmers in latent class 2 and are labeled "Crop Farmers" to indicate their primary focus is on crop production. This does not imply that farmers in latent class 2 do not raise a significant amount of crops (as seen in the descriptive statistics).

According to Table 4, about $70 \%$ of the farmers in the sample are in Latent Class 1 , "Crop Farmers." Farmers in latent class 1 from the central portion of the state are more likely to adopt a switchgrass enterprise under contract than those in the west, while farmers in latent class 1 from the eastern part of the state are less likely to enter into a contract than those in the western part of the state. Higher net returns under contract; having cost-share, and a bio-refinery harvest option all increased the likelihood a farmer in latent class 1 would enter into a contract to produce switchgrass. In contrast, as the length of the contract increases, farmers in latent class 1 are less likely to produce switchgrass for biofuel. 
Table 4. Coefficient estimates for the switchgrass latent class logistic regression model.

\begin{tabular}{|c|c|c|}
\hline & $\begin{array}{l}\text { Latent Class } 1 \\
\text { (Crop Farmers) } \\
\end{array}$ & $\begin{array}{c}\text { Latent Class } 2 \\
\text { (Farmer-Stockman) }\end{array}$ \\
\hline \multicolumn{3}{|c|}{ - } \\
\hline Central & $\begin{array}{l}0.6589 * \\
(0.3718)\end{array}$ & $\begin{array}{c}0.1895 \\
(0.1823)\end{array}$ \\
\hline East & $\begin{array}{l}-0.8711^{*} \\
(0.5279)\end{array}$ & $\begin{array}{c}-1.2858 * * * \\
(0.1757)\end{array}$ \\
\hline Returns & $\begin{array}{l}0.0687 * * \\
(0.0346)\end{array}$ & $\begin{array}{c}0.1599 * * * \\
(0.0122)\end{array}$ \\
\hline Contract Length & $\begin{array}{c}-0.6409 * * * \\
(0.0761)\end{array}$ & $\begin{array}{c}-0.1147 * * * \\
(0.0113)\end{array}$ \\
\hline Harvest & $\begin{array}{c}0.7859 * * * \\
(0.2149)\end{array}$ & $\begin{array}{l}0.2113 * * * \\
(0.0612)\end{array}$ \\
\hline Insurance & $\begin{array}{l}-0.0724 \\
(0.1703)\end{array}$ & $\begin{array}{c}0.2580 * * * \\
(0.0627)\end{array}$ \\
\hline Cost-Share & $\begin{array}{l}0.0149 * * \\
(0.0061)\end{array}$ & $\begin{array}{c}0.0234 * * * \\
(0.0022)\end{array}$ \\
\hline \multicolumn{3}{|c|}{ Latent Class Variables--. } \\
\hline Constant & $\begin{array}{l}2.3277 * * * \\
(0.5249)\end{array}$ & ----- \\
\hline Crop Acres & $\begin{array}{l}-0.0874 \\
(0.1207)\end{array}$ & ---- \\
\hline Hay Acres & $\begin{array}{l}-0.0216 \\
(1.455)\end{array}$ & ----- \\
\hline CRP Acres & $\begin{array}{c}0.0323 \\
(1.6722)\end{array}$ & ----- \\
\hline Per. Cash Rent & $\begin{array}{c}-1.3039 * * * \\
(0.4706)\end{array}$ & ----- \\
\hline Livestock & $\begin{array}{c}-1.1953 * * * \\
(0.3507)\end{array}$ & ----- \\
\hline Baler & $\begin{array}{l}-0.0048 \\
(0.0078)\end{array}$ & ----- \\
\hline Age & $\begin{array}{l}-0.0024 \\
(0.0033)\end{array}$ & ----- \\
\hline College & $\begin{array}{c}0.4198 \\
(0.3407)\end{array}$ & ----- \\
\hline Risk Averse & $\begin{array}{c}0.5148 \\
(0.3183)\end{array}$ & ----- \\
\hline Percent in each class & $69.9 \%$ & $30.1 \%$ \\
\hline \multicolumn{3}{|l|}{ Model Fit Statistics } \\
\hline Number of respondents & & 284 \\
\hline Number of observations & & 1420 \\
\hline Restricted Log-Likelihood & & -1560.03 \\
\hline AIC & & 0.99946 \\
\hline McFadden Pseudo $\mathrm{R}^{2}$ & & 0.5605 \\
\hline
\end{tabular}


Table 5. Descriptive statistics of latent class explanatory variables by latent class. $\dagger$

\begin{tabular}{|c|c|c|c|c|c|c|c|c|c|c|}
\hline & \multicolumn{2}{|c|}{ Mean } & \multicolumn{2}{|c|}{ Std. Dev. } & \multicolumn{2}{|c|}{ Max } & \multicolumn{2}{|c|}{ Min } & \multicolumn{2}{|c|}{ Median } \\
\hline & $\mathrm{LC} 1^{\mathrm{c}}$ & LC2 & LC1 & LC2 & LC1 & LC2 & LC1 & LC2 & LC1 & LC2 \\
\hline Crop Acres & 1567 & 1642 & 1400 & 1395 & 8620 & 7463 & 70 & 186 & 1100 & 1200 \\
\hline Hay Acres & 115 & 125 & 103 & 110 & 500 & 500 & 0 & 0 & 80 & 90 \\
\hline CRP Acres & 138 & 90 & 194 & 127 & 1200 & 648 & 3 & 0 & 75 & 52.5 \\
\hline Per. Cash Rent ${ }^{\mathrm{a}}$ & 39.0 & 40.4 & 40.8 & 36.5 & 100 & 100 & 0 & 0 & 23 & 29 \\
\hline \multirow[t]{2}{*}{ Livestock $^{\mathrm{b}}$} & $54.2 \%$ & $77.1 \%$ & & & & & & & & \\
\hline & $45.8 \%$ & $22.9 \%$ & & & & & & & & \\
\hline \multirow[t]{2}{*}{ Baler $^{b}$} & $54.2 \%$ & $71.1 \%$ & & & & & & & & \\
\hline & $45.8 \%$ & $28.9 \%$ & & & & & & & & \\
\hline Age (years) & 57 & 54 & 12 & 11 & 85 & 85 & 24 & 29 & 56 & 52 \\
\hline \multirow[t]{2}{*}{ College $^{b}$} & $31.8 \%$ & $26.5 \%$ & & & & & & & & \\
\hline & $68.2 \%$ & $73.5 \%$ & & & & & & & & \\
\hline \multirow[t]{2}{*}{ Risk Averse $^{b}$} & $89.1 \%$ & $90.4 \%$ & & & & & & & & \\
\hline & $10.9 \%$ & $9.6 \%$ & & & & & & & & \\
\hline Per. Crop Sales ${ }^{\mathrm{a}}$ & 76.3 & 70.3 & 21.4 & 21.7 & 100 & 97 & 0 & 21 & 85 & 75 \\
\hline Per. Livestock Sales $^{\mathrm{a}}$ & 29.3 & 29.2 & 19.1 & 20.1 & 100 & 73 & 0 & 0 & 25 & 27 \\
\hline
\end{tabular}

${ }^{\mathrm{a}}$ Values are percentages.

${ }^{\mathrm{b}}$ Binary variables. Values are percentage of respondents with livestock, percentage with a baler, percentage with a college education, and percentage indicating they are risk averse in each class.

${ }^{\mathrm{c}}$ Latent class 1 (LC1) includes farmers who are primarily crop farmers. Latent class 2 (LC2) includes farmers more likely to be Farmer-Stockman.

$\uparrow$ Summary statistics are calculated based on highest probability that a respondent falls in latent class 1 or 2. 
According to Table 4, latent class 2 contains about $30 \%$ of the respondents. This latent class is the base category, and these farmers were more likely to raise livestock and have equipment to provide needed feed (e.g. a baler). Therefore, this latent class is labelled "FarmerStockman" to indicate the dual interests in crop and livestock of these farming operations. Farmers in this class from the eastern portion of the state are less likely to adopt a switchgrass contract compared to the western portion, while there was no statistical difference between adoption decisions in the central and western parts of the state. Increasing contract length will reduce willingness to adopt a contract while increasing returns, offering a bio-refinery harvest option, offering insurance, and having a cost-share option will increase the likelihood of adoption for farmers in this latent class.

Figure 4 displays the probability of adopting a less favorable contract for each latent class for 7- and 16-year contract lengths for producers in Central Kansas. The graph shows the probability of contract adoption by farmers assuming the contract has a bio-refinery option, no insurance is offered, and no cost share. Figure 5 shows the probability of adopting a more favorable contract assuming a bio-refinery harvest option, insurance, and a 70\% cost-share option are offered. As noted before, farmers in latent class 1 are less willing to adopt a contract in general. Figure 4 shows that farmers in latent class 2 , those more willing to adopt a contract, will produce switchgrass for $\$ 1$ more per acre than they earn from CRP or hay production at a probability of about $38 \%$ and $18 \%$ for 7 - and 16-year contract lengths, respectively. Figure 5 shows that these probabilities increase to approximately $84 \%$ and $65 \%$, respectively, for the more favorable contract option examined. Probabilities of adoption approach $100 \%$ as net returns per acre increase regardless of contract length for farmers in latent class 2 . In contract scenarios with and without insurance and the seed cost-share attributes (Figures 4 and 5), probabilities of 
adoption are relatively low for farmers in latent class 1 for the 7-year contract length and near zero for the 16-year contract length.

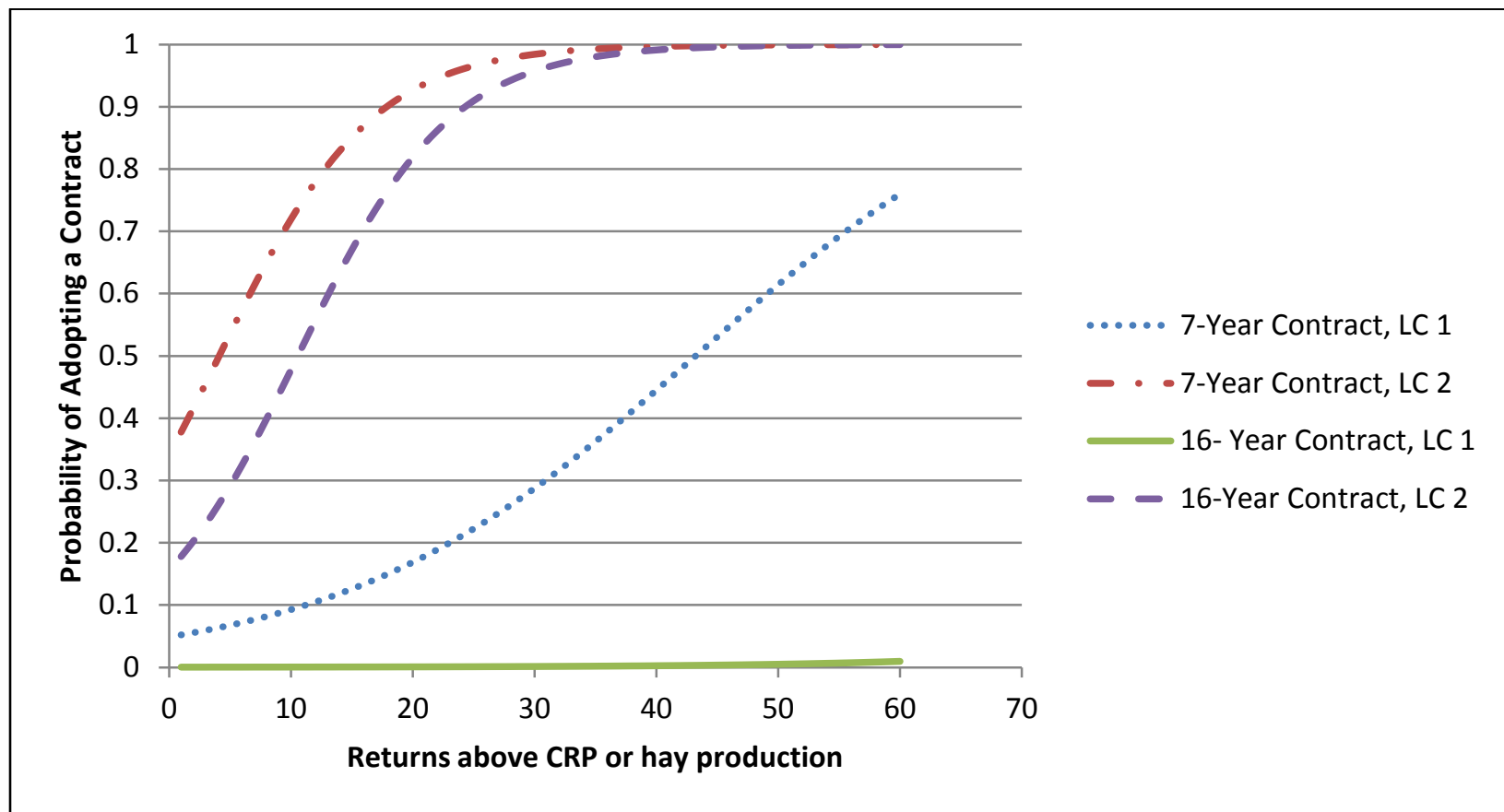

Figure 4. Probability of producing switchgrass in Central Kansas under contract with bio-refinery harvest option, no insurance option, and no seed cost-share option for latent class (LC) 1 (crop farmers) and latent class (LC) 2 (farmer-stockman)

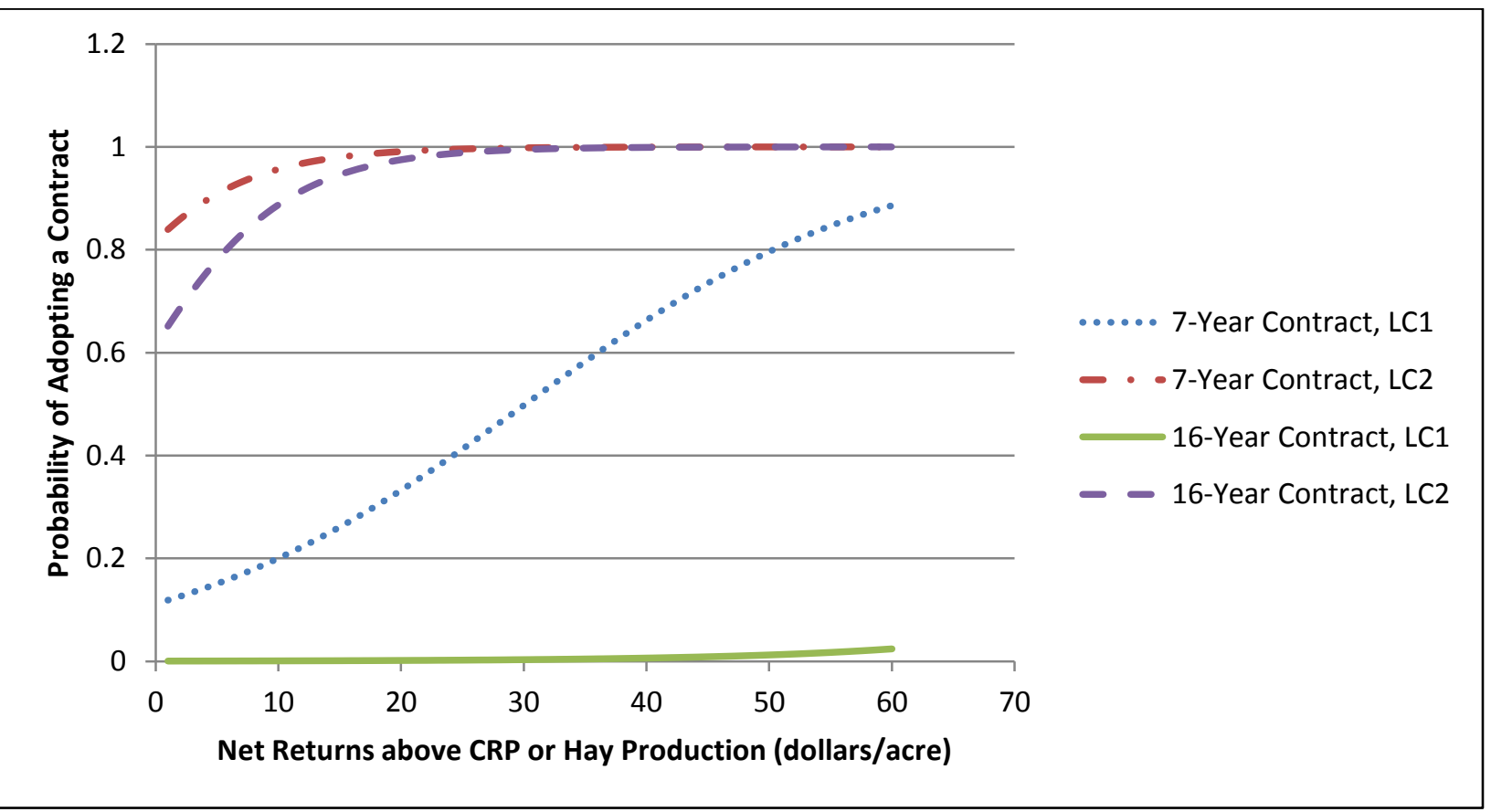

Figure 5. Probability of producing switchgrass in Central Kansas under contract with bio-refinery harvest option, insurance option, and 70\% seed cost-share option for latent class (LC) 1 (crop farmers) and latent class (LC) 2 (farmer-stockman) 


\subsection{Marginal Willingness to Pay}

Table 6 indicates farmers' marginal willingness to pay (MWTP) for various contract attributes based on net return per acre above hay production or CRP. MWTP is defined as $\beta_{i} / \beta_{N R}$, following Hensher et al. (2005) and Greene and Hensher (2003), where $\beta_{i}$ is the latent class parameter for attribute $i=$ contract length, bio-refinery harvest, insurance, and seed cost-share in each latent class and $\beta_{N R}$ is the coefficient on Net Returns. MWTP indicates the willingness to pay for a marginal (i.e., one unit) change in the attribute. The asymptotic standard errors for the WTP measures were estimated using the delta method (Greene, 2008).

Table 6. Willingness to pay estimates for contract attributes.

\begin{tabular}{lcc}
\hline Attribute & $\begin{array}{c}\text { Latent Class 1 } \\
\text { (Crop Farmers) }\end{array}$ & $\begin{array}{c}\text { Latent Class 2 } \\
\text { (Farmer-Stockman) }\end{array}$ \\
\hline \multirow{2}{*}{ Contract length $^{\mathrm{a}}$} & $-9.33^{* * *}$ & $-0.72^{* * *}$ \\
\multirow{2}{*}{ Bio-refinery harvest $^{\mathrm{b}}$} & $(4.087)$ & $(0.061)$ \\
& $11.44^{*}$ & $1.32^{* * *}$ \\
\multirow{2}{*}{ Insurance $^{\mathrm{b}}$} & $(6.246)$ & $(0.376)$ \\
& -1.05 & $1.61^{* * *}$ \\
\multirow{2}{*}{ Seed cost share } & $(2.593)$ & $(0.387)$ \\
& 0.22 & $0.15^{\mathrm{c} * *}$ \\
& $(0.139)$ & $(0.014)$ \\
\hline
\end{tabular}

${ }^{\mathrm{a}}$ Values are in dollars per acre per additional year of contract length.

${ }^{\mathrm{b}}$ Values are in dollars per acre if the attribute is available.

${ }^{c}$ Values are in dollars per acre per percentage of cost share.

Asymptotic standard errors are calculated via the delta method following Greene (2008) and are included in parentheses.

$* * *$ and $*$ indicate statistical significance at $\alpha=0.01$ and 0.10 , respectively.

As expected, the negative sign on contract length indicates farmers will require compensation for entering into longer-term contracts, but the positive signs on WTP for the other attributes indicates that farmers are likely willing to pay (with lower net returns) for the advantages provided by these attributes. Farmers in latent class 1 require $\$ 9.33$ per acre more per year of additional contract length to enter into a contract. Given these farmers may be more crop 
oriented, the less flexibility provided under longer term contracts to switch between crops is likely a greater opportunity cost for this class. Farmers in latent class 2 only require $\$ 0.72$ per acre more per year of additional contract length to enter into a contract. Farmers who have the equipment (e.g. baler) to harvest the crop and who may be used to growing more perennial crops for feed (e.g. hay or alfalfa) may be more familiar with the time commitments required to enter into this type of enterprise.

Farmers in latent class 1 , who may adopt a contract, are willing to pay $\$ 11.44$ per acre for the option of having the bio-refinery harvest their biomass. However, adopters in latent class 2 are willing to pay only $\$ 1.32$ per acre for the bio-refinery harvest option. The difference may be due to the fact that farmers in latent class 2 tend to have baling equipment on-hand (Table 5). Furthermore, a more crop-oriented farmer may desire the additional flexibility provided by this option. MWTP estimates for insurance availability are not statistically significant for latent class 1 , but those in latent class 2 are willing to pay $\$ 1.61$ per acre to have the attribute included in a switchgrass production contract. Farmer-stockman (LC2) may favor the option of insurances as they are more likely to adopt than farmers in latent class 1.

Farmers' MWTP for the cost share for establishment costs examines what a farmer would be willing to pay to increase the percentage of cost share provided to the farmer by 1 percent. That is, the MWTP measure here provides an estimate of how much a farmer would be willing to give up in net returns per acre for a 1 percent increase in cost-share assistance. The MWTP for cost share was $\$ 0.15$ per acre for each one percentage increase in cost-share provided by the biorefinery, ceteris paribus for farmers in latent class 2. Farmers in latent class 2 may be more familiar with the potential costs of production of a perennial crop, indicating their preference for seed establishment cost-share. The Biomass Crop Assistance Program (BCAP) is a government 
program available to farmers that (1) provides up to 50 percent cost-share for establishment of perennial biomass crops, (2) provides an annual payment for up to five years to maintain herbaceous biomass crops, and (3) provides matching funds to harvest and transport biomass (Farm Service Agency, USDA, 2014). Given the similarity in the seed cost share attribute in the experiment and the BCAP, the results here may have some bearing on the effectiveness of BCAP in the study region under the prevailing market conditions in which the survey was administered. For the majority of farmers (who are in latent class 1), the presence of a seed-cost share incentive is likely not a significant factor for promoting the potential adoption of switchgrass, limiting the potential usefulness of this tool in the BCAP. It may be the case that farmers would rather take advantage of cost share and incentive options related to biomass retrieval rather than for establishment and maintenance cost-share.

\section{Conclusions and Further Research}

Switchgrass has potential to help reduce the nation's dependence on nonrenewable sources of energy, but much uncertainty exists as to its viability in Kansas. Kansas farmers were surveyed to assess their willingness to grow switchgrass as a biofuel feedstock under alternative contract scenarios. Results in the study area show that contract attributes positively affect farmers' potential decisions to enter into a contract to grow switchgrass. These attributes include net returns, bio-refinery harvest options, insurance availability, and seed cost-share assistance.

Contract length negatively affects farmers' decisions on which contract to choose, and indicates farmers prefer shorter-term contracts with such new and potentially uncertain enterprises.

A latent class model was estimated to predict the likelihood farmers would choose to adopt a contract to grow switchgrass for bioenergy over "opting out." The model allows for coefficient estimates for each respondent to be aggregated with choice-specific characteristics in 
a stated-choice framework. Latent classes account for unobserved respondent heterogeneity due to farm or farmer characteristics. Within the latent classes, farmers who are more likely to enter into a switchgrass contract are more willing to pay more for a bio-refinery harvest option, but require more compensation to enter into long-term contracts. Calculated probabilities show that farmers are about $20 \%$ more likely to adopt shorter contracts. Livestock producers in this survey group are less likely to adopt a switchgrass contract as are farmers with a higher percentage of cash-rented land.

WTP estimates show that contract length is an important attribute (maybe the most important attribute) in determining whether a farmer will produce switchgrass for bioenergy for each latent class. In each class, farmers require some payment ranging from $\$ 9.33$ (for crop farmers) to $\$ 0.72$ (for farmer-stockman) per acre per additional year length added to a contract to produce switchgrass. In addition, farmers see a seed-cost share arrangement as beneficial to entering into a switchgrass producing contract and adopters are willing to pay about $\$ 0.15$ per acre per percentage point increase in the share of establishment costs paid by the bio-refinery.

A primary area of further research is to determine how bioenergy crop characteristics, storage, and transportation issues affect farmers' decisions to grow a bioenergy crop. Risk aversion is also important when assessing farmers' willingness to adopt new technology or practices and could affect their decisions. The latent class logit model presented here attempts to control for these, but it does not explain how farmers base their decisions because of these characteristics specifically.

The information gained from this survey may be extremely useful for determining accurate estimates of supply for biorefineries considering the production of cellulosic ethanol from switchgrass in the Midwest. Model results provide evidence of the contracting requirements 
and extent of adoption, which may be extremely useful for siting of and determining the biomass supply area around the refinery. In addition, policy-makers may find the results here useful for examining the provision of cost-share assistance; helping to provide outreach to farmers and industry regarding contract negotiations; and providing guidance concerning cellulosic ethanol production targets. 


\section{Acknowledgements}

Funding for this project came from the South Central Sun Grant Initiative and Department of Transportation (Award No. DTOS59-07-G-00053), with additional funds from the National Science Foundation, EPSCoR Division, Research Infrastructure Improvement (Award No. 0903806), and support from National Science Foundation Grant: From Crops to Commuting:

Integrating the Social, Technological, and Agricultural Aspects of Renewable and Sustainable Biorefining (I-STAR); NSF Award No.: DGE-0903701. 


\section{References}

Alexander, C., Ivanic, R., Rosch, S., Tyner, W., Wu, S. Y., \& Yoder, J. R. (2012). Contract Theory and Implications for Perennial Energy Crop Contracting. Energy Economics, 34(4), 970979.

Altman, I., Boessen, C. R., \& Sanders, D. R. (2007). Contracting for Biomass: Supply Chain Strategies for Renewable Energy. Selected paper for presentation at the Southern Agricultural Economics Association Annual Meetings. Mobile, Alabama, February 3-6.

Bangsund, D. A., DeVuyst, E. A., \& Leistritz, F. L. (2008). Evaluation of Breakeven Farmgate Switchgrass Prices in South Central North Dakota. Agribusiness and Applied Economics Report No. 632, North Dakota State University, Agribusiness and Applied Economics.

Boxall, P. C., \& Adamowicz, W. L. (2002). Understanding Heterogeneous Preferences in Random Utility Models: A Latent Class Approach. Environmental and Resource Economics, 23, 421-446.

Bransby, D. (1998). Interest among Alabama Farmers in Growing Switchgrass for Energy. Paper presented at BioEnergy '98: Expanding Bioenergy Partnerships. Madison, WI.

Breffle, W. S., Morey, E. R., \& Thacher, J. A. (2011). A Joint Latent-Class Model: Combining Likert-Scale Preference Statements with Choice Data to Harvest Preference Heterogeneity. Environmental and Resource Economics, 50(1), 83-110.

Caldas, M.M., Bergtold, J.S., Peterson, J.M., Graves, R., Earhart, D., Gong, S., Lauer, B. and Brown, J.C. (2014). Factors Affecting Famers' Willingness to Grow Alternative Biofuel Feedstocks Across Kansas. Biomass and Bioenergy 66, 223 - 231.

Colombo, S., Hanley, N., \& Louviere, J. (2009). Modeling Preference Heterogeneity in Stated Choice Data: An Analysis for Public Goods Generated by Agriculture. Agricultural Economics, 40(3), 307-322.

Cook, R.D. \& Nachtsheim, C.J. (1989). Computer-Aided Blocking of Factorial and ResponseSurface Designs. Technometrics, 31, 339-346.

De la Torre Ugarta, D. G., English, B. C., \& Jensen, K. (2007). Sixty Billion Gallons by 2030: Economic and Agricultural Impacts on Ethanol and Biodiesel Expansion. American Journal of Agricultural Economics, 89(5), 1290-1295.

Dicks, M. R., Campiche, J., de la Torre Ugarte, D., Hellwinckel, C., Bryant, H. L., \& Richardson, J. W. (2009). Land Use Implications of Expanding Biofuel Demand. Journal of Agricultural and Applied Economics, 41(2), 435-453.

Epplin, F. M., Clark, C. D., Roberts, R. K., \& Hwang, S. (2007). Challenges to the Development of a Dedicated Energy Crop. American Journal of Agricultural Economics, 89(5), 1296-1302. 
Farm Service Agency, USDA. (2014, June). Biomass Crop Assistance Programs. Retrieved from http://www.fsa.usda.gov/FSA/webapp?area=home\&subject=ener\&topic=bcap, Accessed July $18,2014$.

Fewell, J. E., Lynes, M. K., Williams, J. R., \& Bergtold, J. S. (2013). Kansas Farmers' Interest and Preferences for Growing Cellulosic Bioenergy Crops. Journal of the American Society of Farm Managers and Rural Appraisers, 76:131-152.

Gallagher, P. W., Dikeman, M., Fritz, J., Wailes, E., Gauthier, W., \& Shapouri, H. (2003). Supply and Social Cost Estimates for Biomass Crop Residues in the United States. Environmental and Resource Economics, 24(4), 335-358.

Glassner, D. A., Hettenhaus, J. R., \& Schechinger, T. M. (1998). Corn Stover Collection Project. Paper presented at BioEnergy '98: Expanding Bioenergy Partnerships. Madison, Wisconsin, October 4-8.

Graham, R. L. (1994). An Analysis of the Potential Land Base for Energy Crops in the Conterminous United States. Biomass and Bioenergy, 6(3), 175-189.

Graham, R. L., Nelson, R., Sheehan, J., Perlack, R. D., \& Wright, L. L. (2007). Current and Potential U.S. Corn Stover Supplies. Agronomy Journal, 99(1), 1-11.

Greene, W. H. (2007). NLOGIT Version 4.0: Reference Guide. Plainview, New York: Econometric Software, Inc.

Greene, W. H. (2008). Econometric Analysis (6th Edition ed.). Upper Saddle River, New Jersey: Pearson Prentice Hall.

Greene, W. H., \& Hensher, D. A. (2003). A Latent Class Model for Discrete Choice Analysis: Contrasts with Mixed Logit. Transportation Research Part B, 37(8), 681-698.

Griffith, A. P., Epplin, F. M., \& Redfearn, D. D. (2010). Cost of Producing Switchgrass for Biomass Feedstock. Oklahoma State University, Agricultural Economics and Plant and Soil Sciences, Stillwater, OK.

Heid, W. G. (1984). Turning Great Plains Crop Residues and Other Products into Energy. Agricultural Economic Report No. 523, United States Department of Agriculture, Economic Research Service, Washington, D.C.

Hensher, D. A., Rose, J. M., \& Greene, W. H. (2005). Applied Choice Analysis: A Primer. New York: Cambridge University Press.

Hipple, P. C., \& Duffy, M. D. (2002). Farmers' Motivations for Adoption of Switchgrass. In J. Janich, \& A. Whipkey (Eds.), Trends in New Crops and New Uses (pp. 252-266). Alexandria, VA: ASHA Press. 
Jensen, K., Clark, C. D., Ellis, P., English, B., Menard, J., Walsh, M., \& de la Torre Ugarte, D. (2007). Farmer Willingness to Grow Switchgrass for Energy Production. Biomass and Bioenergy, 31(11), 773-781.

Kansas Farm Management Association”Summary Reports by Region.” 2010 Available at: http://www.agmanager.info/kfma/

Kelsey, K. D., \& Franke, T. C. (2009). The Producers' Stake in the Bioeconomy: A Survey of Oklahoma Producers' Knowledge and Willingness to Grow Dedicated Biofuel Crops. Journal of Extension, 47(1).

Larson, J. A., English, B. C., \& Lambert, L. (2007, November 20). Economic Analysis of the Conditions for Which Farmers will Supply Biomass Feedstocks for Energy Production. Retrieved May 2011, from Agricultural Marketing Resource Center: http://www.agmrc.org/media/cms/2007UTennProjDeliverable_9BDDFC4C2F4E5.pdf

Louviere, J. J., Hensher, D. A., \& Swait, J. D. (2000). Stated Choice Methods: Analysis and Application. New York: Cambridge University Press.

Mapemba, L., \& Epplin, F. M. (2004). Lignocellulosic Biomass Harvest and Delivery Cost. Paper presented at the Southern Agricultural Economics Association Annual Meetings, February 14-18. Tulsa, OK.

McLaughlin, S. B., \& Walsh, M. E. (1998). Evaluating Environmental Consequences of Producing Herbaceous Crops for Bioenergy. Biomass and Bioenergy, 14(4), 317-324.

McLaughlin, S. B., de la Torre Ugarte, D. G., Garten, J. C., Lynd, L. R., Sanderson, M. A., Tolbert, V. R., \& Wolf, D. D. (2002). High-Value Renewable Energy from Prairie Grasses. Environmental Science and Technology, 36(10), 2122-2129.

Meyerhoff, J., Bartczak, A., \& Liebe, U. (2012). Protester or Non-Protester: A Binary State? On the Use (and Non-Use) of Latent Class Models to Analyze Protesting in Economic Valuation. The Australian Journal of Agricultural and Resource Economics, 56(3), 438-454.

National Agricultural Statistics Service. (2009, February 03). 2007 Census Publications. Retrieved May 2011, from USDA National Agricultural Statistics Service: http://www.agcensus.usda.gov/Publications/2077/Full_Report/Volume_1,_Chapter_1_State_Lev el/Kansas/index.asp

Nelson, R., Langemeier, M., Williams, J., Rice, C., Staggenborg, S., Pfromm, P. Nippert, J. (2010). Kansas Biomass Resource Assessment: Assessment and Supply of Select Biomass-based Resources. Research report prepared for the Kansas Bioscience Authority, Olathe, KS.

Nguyen, N.K. \& Miller, A. (1992). A Review of Exchange Algorithms for Constructing Discrete D-optimal Designs. Computational Statistics \& Data Analysis, 14, 489-498. 
Ohlenbusch, P. D. (1997). Establishing Native Grasses. Kansas State University Agricultural Experiment Station and Cooperative Extension Service MF-2291, Kansas State University, Department of Agronomy, Manhattan, KS.

Paine, L. K., Peterson, T. L., Undersander, D. J., Rineer, K. C., Bartelt, G. A., Temple, S. A., Klemme, R. M. (1996). Some Ecological and Socio-Economic Considerations for Biomass Energy Crop Production. Biomass and Bioenergy, 10(4), 231-242.

Pannell, D. J., Marshall, G. R., Barr, N., Curtis, A., Vanclay, F., \& Wilkinson, R. (2006). Understanding and Promoting Adoption of Conservation Practices by Rural Landholders. Australian Journal of Experimental Agriculture, 46, 1407-1424.

Paulrud, S., \& Laitila, T. (2010). Farmers' Attitudes about Growing Energy Crops: A Choice Experiment Approach. Biomass and Bioenergy, 34(12), 1770-1779.

Perlack, R. D., Wright, L. L., Turhollow, A. F., Graham, R. L., Stokes, B. J., \& Erbach, D. C. (2005). Biomass as Feedstock for a Bioenergy and Bioproducts Industry: The Technical Feasibility of a Billion-Ton Annual Supply. Oak Ridge National Laboratory, Oak Ridge, TN.

Perrin, R., Vogel, K., Schmer, M., \& Mitchell, R. (2008). Farm-Scale Production Cost of Switchgrass for Biomass. BioEnergy Research, 1(1), 91-97.

Qualls, D. J., Jensen, K. L., Clark, C. D., English, B. C., Larson, J. A., \& Yen, S. T. (2012). Analysis of Factors Affecting Willingness to Produce Switchgrass in the Southeastern United States. Biomass and Bioenergy, 39, 159-167.

Rajagopal, D., Sexton, S. E., Roland-Holst, D., \& Zilberman, D. (2007). Challenge of Biofuel: Filling the Tank Without Emptying the Stomach? Environmental Resource Letters, 2(4), 044004. Retrieved May 2011, from Environmental Research Letters: http://iopscience.iop.org/1748-9326

Rigdon, A. R., Maier, D. E., Vadlani, P., \& Jumpponen, A. (2011). Evaluation of Composition and Enzymatic Activity Changes of Sorghum Biomass Under Various Storage Conditions. Manhattan, KS, April 27-28: Poster presented at Kansas State University Bioenergy Symposium: Mapping Sustainable Bioenergy Opportunities in the Central Great Plains--Feedstocks, Land Use, Markets, and Socioeconomic Aspects.

Roe, B., Sporleder, T. L., \& Belleville, B. (2004). Hog Producer Preferences for Marketing Contract Attributes. American Journal of Agricultural Economics, 86(1), 115-123.

SAS Institute, Inc. (2008). SAS for Windows, Version 9.2. Cary, NC.

Stricker, J. A., Segrest, S. A., Rockwood, D. L., \& Prine, G. M. (2000). Model Fuel Contract-Co-firing Biomass with Coal. Paper presented at the Soil and Crop Science Society of Florida and Florida Nematology Forum, 60th Annual Meeting. Tallahassee, Florida, September 20-22. 
Teel, A., Barnhart, S., \& Miller, G. (2003). Management Guide for the Production of Switchgrass for Biomass Fuel in Southern Iowa. Iowa State University, University Extension Publication PM 1710, Iowa State University, Department of Agronomy, Ames, IA.

Train, K. E. (2003). Discrete Choice Methods with Simulation. Cambridge, UK: Cambridge University Press.

USDA (2006). Crop Residue Removal for Biomass Energy Production: Effects on Soils and Recommendations. NRCS Agronomy Technical Note No. 15. August.

Walsh, M. E., de la Torre Ugarte, D. G., Shapouri, H., \& Slinsky, S. P. (2003). Bioenergy Crop Production in the United States: Potential Quantities, Land Use Changes, and Economic Impacts on the Agricultural Sector. Environmental and Resource Economics, 24(4), 313-333.

Wilhelm, W. W., Johnson, J. M., Hatfield, M. L., Voorhees, W. B., \& Linden, D. R. (2004). Crop and Soil Productivity Response to Corn Residue Removal: A Literature Review. Agronomy Journal, 96(1), 1-17.

Wright, L. (2007). Historical Perspective on How and Why Switchgrass was Selected as a "Model" High-Potential Energy Crop. Prepared by Oak Ridge National Laboratory managed by UT-Battelle, LLC for the U.S. Department of Energy under contract DE-AC05-00OR22725, Oak Ridge National Laboratory, Oak Ridge, Tennessee. 